Красинский Владислав Вячеславович

доктор юридических наук, член Общественного

консультативного научно-методического Совета

при ЦИК России

\title{
Кандидаты в депутаты Государственной Думы Федерального Собрания Российской Федерации пятого и шестого созывов: сравнительный анализ партийных списков и предложения по совершенствованию законодательства
}

В статье анализируются партийные списки и сведения о кандидатах в депутаты Государственной Думы Федерального Собрания Российской Федерации пятого и шестого созывов. Автором рассмотрены некоторые проблемы регистрации кандидатов в депутаты Государственной Думы и даны предложения по совершенствованию законов о выборах.

Ключевые слова: выборы, избирательный процесс, политические партии, кандидаты в депутаты, партийные списки, Государственная Дума Федерального Собрания Российской Федерации.

The article examines federal lists of candidates and data on candidates of the State Duma of the Federal Assembly of the fifth and sixth convocations. The author studies some problems of registration of candidates of the State Duma and offers on perfection of laws on elections are given.

Key words: elections, electoral process, political parties, candidates, federal lists of candidates, State Duma of the Federal Assembly of the Russian Federation.

Красинский B.B. Кандидаты в депутаты Государственной Думы Федерального Собрания Российской Федерации пятого и шестого созывов: сравнительный анализ партийных списков и предложения по совершенствованию законодательства (сообщества) как элемент политической системы российского общества // Современное право. 2012. № 4-5; www.krasinskiy.ru

Одним из важнейших и крупномасштабных общественно-политических мероприятий в нашей стране являются выборы депутатов Государственной Думы Федерального Собрания Российской Федерации. В ходе данной избирательной кампании каждый из нас осуществляет выбор между политическими лидерами, их программами и партиями, претендующими на осуществление государственной власти и народного представительства. Принимая политические решения, мы основываем свои политические предпочтения (поверхностно-ситуативные или глубоко осмысленные) на личных симпатиях и имеющихся сведениях о лидерах политических партий, наиболее известных региональных функционерах, партийных программах и мероприятиях.

Помимо сведений о кандидатах, идеологических установках партий, предоставляемых СМИ и избирательными комиссиями в ходе выборов, информацию о кандидатах, избирательных объединениях и партийных списках можно получить в день голосования на избирательном участке. В 
помещении для голосования можно ознакомиться с биографическими данными кандидатов, сведениями об их доходах и имуществе, неснятых и непогашенных судимостях, а также с информацией о предоставлении кандидатами недостоверных сведений (если она имеется).

К сожалению, объем подобных сведений на избирательных участках зачастую недостаточен. Представляется, что целостное представление о качественных характеристиках будущего депутатского корпуса Государственной Думы Федерального Собрания Российской Федерации дает только анализ зарегистрированных ЦИК России федеральных списков политических партий. Он позволяет выяснить число участников избирательной кампании, состав федеральных списков, количество региональных групп, информацию о выдвинутых кандидатах и представленных ими недостоверных сведениях.

Целью настоящей статьи является сравнительное исследование зарегистрированных партийных списков и соответствующих сведений о кандидатах, выдвинутых политическими партиями, принимавшими участие в выборах депутатов Государственной Думы Федерального Собрания Российской Федерации пятого и шестого созывов, а также подготовка предложений по совершенствованию отдельных законодательных актов о выборах и смежных законов.

В выборах депутатов Государственной Думы Федерального Собрания Российской Федерации пятого созыва участвовали 11 политических партий: «Аграрная партия России», Всероссийская политическая партия «Гражданская сила», «Демократическая партия России», Всероссийская политическая партия «ЕДИНАЯ РОССИЯ», Российская объединенная демократическая партия «ЯБЛОКО», «Справедливая Россия: Родина / Пенсионеры / Жизнь», «Патриоты России», «Коммунистическая партия Российской Федерации», политическая партия «Союз правых сил», «Партия социальной справедливости» и «Либерально-демократическая партия России» ${ }^{1}$.

Выдвижение и регистрация федеральных списков кандидатов регулировались статьей 36 Федерального закона «О выборах депутатов Государственной Думы Федерального Собрания Российской Федерации».

Состав федеральных списков и порядок размещения в них кандидатов определялись политическими партиями. Федеральный список разбивался (полностью или частично) на региональные группы кандидатов, соответствующие субъекту Российской Федерации, группе субъектов Российской Федерации, части территории субъекта Российской Федерации.

Число региональных групп кандидатов не могло составлять менее 80. Региональная часть списка должна была охватывать все субъекты

${ }^{1}$ Федеральные списки кандидатов в депутаты Государственной Думы Федерального Собрания Российской Федерации пятого созыва, выдвинутые политическими партиями и зарегистрированные Центральной избирательной комиссией Российской Федерации. Специальный информационный выпуск ЦИК РФ // Рос. газ. 2007. 2 декабря. 208 с. 
Российской Федерации. В общефедеральную часть федерального списка кандидатов включалось не более трех кандидатов. Общее число кандидатов, включенных в федеральный список, не могло превышать 600 человек.

Согласно части 9.1 Федерального закона от 21 июля 2007 года № 188-Ф3 «О внесении изменений в Федеральный закон «О выборах депутатов Государственной Думы Федерального Собрания Российской Федерации» партии получили право определять региональную группу кандидатов, к которой будут отнесены поданные за федеральный список кандидатов голоса избирателей, проживающих за пределами территории Российской Федерации ${ }^{1}$. Данным правом воспользовались Всероссийская политическая партия «ЕДИНАЯ РОССИЯ», политическая партия «Коммунистическая партия Российской Федерации», политическая партия «СПРАВЕДЛИВАЯ РОССИЯ: РОДИНА, ПЕНСИОНЕРЫ, ЖИЗНЬ», политическая партия «Либерально-демократическая партия России», Российская объединенная демократическая партия «ЯБЛОКО» и политическая партия «Союз правых сил».

Исходя из сведений о численности избирателей, ЦИК России определила границы частей территорий и перечень частей территорий 26 субъектов Российской Федерации, которым могли соответствовать региональные группы кандидатов при проведении выборов депутатов Государственной Думы Федерального Собрания Российской Федерации пятого созыва ${ }^{2} .59$ субъектов Российской Федерации не делились на части территории, которым могли соответствовать региональные группы кандидатов. В 26 субъектах Российской Федерации число частей территории, которым могли соответствовать региональные группы кандидатов, составило 94.

«Аграрная партия России» выдвинула на выборах 469 кандидатов, 3 из которых были включены в общефедеральную часть списка, а остальные распределены в 93 региональных группах. 5 региональных групп было образовано в Краснодарском крае, по 4 региональных группы - в Республике Татарстан, Москве, Московской, Нижегородской, Ростовской областях, 3 группы - в Волгоградской области, по 2 группы - в Приморском крае, Иркутской, Новосибирской, Оренбургской и Челябинской областях.

«Гражданская сила» и «Партия социальной справедливости» выдвинули наименьшее число кандидатов - 255 и 259 соответственно. Общефедеральная часть списка «Гражданской силы» включала 3 кандидатов и 90 региональных групп. 5 региональных групп было образовано в Москве, 3 группы - в Московской области, по 2 группы - в Республике Башкортостан, Краснодарском крае, Воронежской, Нижегородской, Новосибирской, Ростовской, Самарской областях и Санкт-Петербурге.

${ }^{1}$ Рос. газ. 2007. 25 июля.

2 Постановление ЦИК России от 8 августа 2007 года № 23/186-5 «Об определении границ и перечня частей территорий субъектов Российской Федерации, которым могут соответствовать региональные группы кандидатов на выборах депутатов Государственной Думы Федерального Собрания Российской Федерации пятого созыва» // Рос. газ. 2007. 11 августа. 
«Партия социальной справедливости» образовала максимальное общее количество региональных групп - 109 и максимальное количество групп в субъекте Российской Федерации - 6.6 региональных групп было образовано в Москве, 5 - в Московской и Свердловской областях, 4 - в Республике Башкортостан и Санкт Петербурге, 3 - в Нижегородской и Новосибирской областях, 2 - в Республике Дагестан, Краснодарском и Красноярском краях, Оренбургской и Тульской областях.

В списке Демократической партии России был 541 человек, 3 человека в общефедеральной части списка, остальные - в составе 99 региональных групп. 5 региональных групп было образовано в Ростовской и Свердловской областях, 4 - в Республике Татарстан и Челябинской области, 3 - в Алтайском крае, Нижегородской, Самарской, Саратовской областях и в Москве, 2 - в Пермском, Приморском, Ставропольском краях, Волгоградской, Воронежской, Московской, Новосибирской, Оренбургской, Тульской областях и в Санкт-Петербурге.

Наибольшее число кандидатов, допустимое законом, выдвинула «Единая Россия» - 600 человек. В общефедеральную часть списка был включен 1 кандидат - Президент Российской Федерации Путин В.В. 599 кандидатов были включены в состав 83 региональных групп. В отличие от других партийных списков, региональные группы «Единой России» возглавлялись высшими должностными лицами субъектов Российской Федерации (президентами республик, губернаторами, главами администраций), депутатами Государственной Думы или федеральными министрами. 3 региональные группы были образованы в Волгоградской области и 2 группы - в Воронежской области. Голоса избирателей, проживающих за пределами территории Российской Федерации, были отнесены к региональной группе «Калининградская область».

Список Российской объединенной демократической партии «Яблоко» состоял из 341 человека. 3 кандидата были включены в общефедеральную часть списка, остальные - распределены среди 98 региональных групп. 5 региональных групп партия образовала в городе Санкт-Петербург, 4 - в Республике Башкортостан, 3 - в Краснодарском и Красноярском краях, Волгоградской, Московской, Нижегородской, Новосибирской, Ростовской областях и городе Москве, 2 - в Приморском крае, Воронежской, Омской, Оренбургской и Тульской областях. Голоса избирателей, проживающих за пределами территории Российской Федерации, были отнесены к региональной группе «г. Москва - Донская, г. Москва - Люблинская, г. Москва - Царицынская, г. Москва - Черемушкинская».

В списке партии «Справедливая Россия: Родина / Пенсионеры / Жизнь» было 546 кандидатов, 3 из которых состояли в общефедеральной части, а остальные - в составе 90 региональных групп. 5 региональных групп было образовано в Краснодарском крае, 3 - в Московской области, 2 - в Республиках Башкортостан, Татарстан, Свердловской, Тульской и Челябинской областях. $\mathrm{K}$ региональной группе «Ямало-Ненецкий 
автономный округ» были отнесены поданные за федеральный список голоса избирателей, проживающих за пределами территории России.

«Патриоты России» выдвинули 433 кандидата. В общефедеральную часть списка были включены 3 кандидата, 430 кандидатов вошли в состав 87 региональных групп. 2 региональных группы были образованы в Республике Башкортостан, Алтайском, Краснодарском и Пермском краях, Иркутской, Московской и Свердловской областях.

«Коммунистическая партия Российской Федерации» выдвинула 514 кандидатов, 3 из которых были включены в общефедеральную часть списка, остальные распределены в 85 региональных группах. Так же, как и у «Аграрной партии России» и партии «Справедливая Россия: Родина / Пенсионеры / Жизнь», максимальное количество региональных групп (5) было образовано в составе Краснодарского края. По 3 региональных группы были от Республик Башкортостан, Татарстан, Нижегородской и Ростовской областей, по 2 - от Приморского и Ставропольского краев, Воронежской, Новосибирской и Свердловской областей. К региональной группе «Курская область» были отнесены поданные за федеральный список голоса избирателей, проживающих за пределами территории России.

В списке политической партии «Союз правых сил» было 300 человек: 3 кандидата в общефедеральной части, остальные - в составе региональных групп. По 3 региональных группы было образовано в Краснодарском крае и Московской области, по 2 - в Республиках Башкортостан, Дагестан и в Нижегородской области. Голоса избирателей, проживающих за пределами территории Российской Федерации, были отнесены к региональной группе «Амурская область, Еврейская автономная область».

Либерально-демократическая партия России выдвинула 356 кандидатов, 3 из которых были в общефедеральной части списка, а остальные - в составе 87 региональных групп. 3 региональных группы было образовано в Краснодарском крае, 2 - в Республиках Башкортостан, Татарстан, Воронежской, Иркутской, Московской, Ростовской, Самарской, Саратовской, Свердловской и Челябинской областях. Голоса избирателей, проживающих за пределами территории Российской Федерации, были отнесены к региональной группе «город Москва».

По результатам проведенных выборов депутатские мандаты в Государственной Думе Федерального Собрания Российской Федерации пятого созыва были распределены между 4 политическими партиями. Всероссийская политическая партия «ЕДИНАЯ РОССИЯ» получила 315 депутатских мест в парламенте, Политическая партия «Коммунистическая партия Российской Федерации» - 57, Политическая партия «СПРАВЕДЛИВАЯ РОССИЯ: РОДИНА / ПЕНСИОНЕРЫ / ЖИЗНЬ» - 38, Политическая партия «Либерально-демократическая партия России» $-40^{1}$.

${ }^{1}$ Постановление ЦИК России от 8 декабря 2007 года № 72/591-5 «О результатах выборов депутатов Государственной Думы Федерального Собрания Российской Федерации пятого созыва» // Рос. газ. 2007. 11 декабря. 
По сравнению с выборами 2007 года, к 2011 г. произошло сокращение количества зарегистрированных политических партий, имеющих право принимать участие в выборах ${ }^{1}$. Это привело к росту конкуренции между кандидатами.

Согласно Федеральному закону от 22 июля 2008 года № 144-Ф3 «О внесении изменений в статьи 30 и 33 Федерального закона «О политических партиях» с 1 января 2009 года было увеличено государственное финансирование политических партий - с 5 до 20 рублей, умноженных на число голосов избирателей, полученных федеральным списком кандидатов, выдвинутым политической партией².

В 2009 году был реализован комплекс законодательных инициатив Президента Российской Федерации, сформулированный в Послании Федеральному Собранию Российской Федерации 5 ноября $2008 \Gamma^{3}$.

В частности, были созданы гарантии представительства избирателям, проголосовавшим за так называемые «малые» партии (партии, получившие от 5 до $7 \%$ голосов) $)^{4}$. Законодатель поэтапно снизил минимальное количество членов организации, требуемое для регистрации новой политической партии 5 . Политические партии, сумевшие набрать на выборах в Государственную Думу Федерального Собрания Российской Федерации более $5 \%$ голосов либо создавшие фракции в более чем трети региональных парламентов, получили освобождение от сбора подписей 6 . На выборах всех уровней был отменен избирательный залог ${ }^{7}$. Впервые были созданы гарантии освещения работы парламентских партий в государственных $\mathrm{CM}^{8}$.

1 Так, в 2008 г. Аграрная партия России объединилась с Всероссийской политической партией «Единая Россия», а Партия социальной справедливости - с политической партией «Справедливая Россия». «Союз правых сил», «Гражданская сила» и «Демократическая партия России» объявили о самороспуске и создали Всероссийскую политическую партию «Правое Дело».

2 Рос. газ. 2008. 25 июля.

3 Рос. газ. 2008. 6 ноября.

${ }^{4}$ Федеральный закон от 12 мая 2009 г. № 94-Ф3 «О внесении изменений в отдельные законодательные акты Российской Федерации в связи с повышением представительства избирателей в Государственной Думе Федерального Собрания Российской Федерации» // Рос газ. 2009. 15 мая.

5 Федеральный закон от 28 апреля 2009 г. № 75-Ф3 «О внесении изменений в Федеральный закон «О политических партиях» в связи с поэтапным снижением минимальной численности членов политических партий».

6 Федеральный закон от 3 июня 2009 г. № 108-Ф3 «О внесении изменений в отдельные законодательные акты Российской Федерации в связи с сокращением количества подписей избирателей в поддержку выдвижения федеральных списков кандидатов на выборах депутатов Государственной Думы Федерального Собрания Российской Федерации и уточнением оснований для регистрации кандидатов, списков кандидатов на выборах в органы государственной власти и органы местного самоуправления» // Рос. газ. 2009. 10 июня.

Федеральный закон от 9 февраля 2009 г. № 3-Ф3 «О внесении изменений в отдельные законодательные акты Российской Федерации в связи с отменой избирательного залога при проведении выборов».

8 Федеральный закон от 12 мая 2009 г. № 95-Ф3 «О гарантиях равенства парламентских партий при освещении их деятельности государственными общедоступными телеканалами и радиоканалами» // Рос. газ. 2009. 15 мая. 
Федеральный закон от 19 октября 2011 года № 287-ФЗ «О внесении изменений в отдельные законодательные акты Российской Федерации в связи со снижением минимального процента голосов избирателей, необходимого для допуска к распределению депутатских мандатов в Государственной Думе Федерального Собрания Российской Федерации» до $5 \%$ снизил заградительный барьер на выборах депутатов Государственной Думы Федерального Собрания Российской Федерации ${ }^{1}$.

Совершенствование федерального законодательства о выборах и уменьшение числа субъектов Российской Федерации в результате реформы государственного строительства повлияло на количество региональных групп в составе партийных списков кандидатов: их количество уменьшилось.

В соответствии с Федеральным законом от 23 февраля 2011 г. № 17-Ф3 «O внесении изменений в Федеральный закон «О выборах депутатов Государственной Думы Федерального Собрания Российской Федерации» минимально необходимое число региональных групп было сокращено до $70^{2}$. Кроме того, законодатель предусмотрел возможность исключения из федерального списка кандидатов нескольких региональных групп (но не более 10).

Федеральным законом от 29 ноября 2010 года № 325-Ф3 «О внесении изменения в статью 36 Федерального закона «О выборах депутатов Государственной Думы Федерального Собрания Российской Федерации» общефедеральная часть федерального списка кандидатов была расширена до

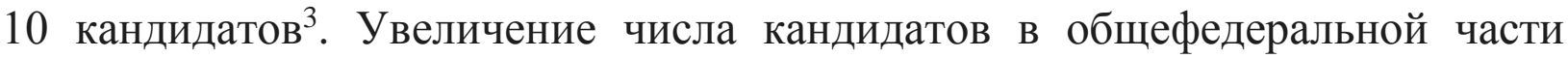
было обосновано необходимостью повышения уровня информированности избирателей о политических партиях, их программах и их лидерах.

Исходя из сведений о численности избирателей, ЦИК России определила границы частей территорий и перечень частей территорий 25 субъектов Российской Федерации, которым могли соответствовать региональные группы кандидатов при проведении выборов депутатов Государственной Думы Федерального Собрания Российской Федерации шестого созыва ${ }^{4} .58$ субъектов Российской Федерации не делились на части территории, которым могли соответствовать региональные группы кандидатов. В 25 субъектах Российской Федерации число частей территории, которым могли соответствовать региональные группы кандидатов, составило 93.

В выборах депутатов Государственной Думы Федерального Собрания Российской Федерации шестого созыва участвовали 7 политических партий: политическая партия СПРАВЕДЛИВАЯ РОССИЯ, Либерально-

\footnotetext{
${ }^{1}$ Рос. газ. 2011. 21 октября.

${ }^{2}$ Рос. газ. 2011. 25 февраля.

${ }^{3}$ Рос. газ. 2010. 3 декабря.
}

${ }^{4}$ Постановление ЦИК России от 3 августа 2011 года № 23/235-6 «Об определении границ и перечня частей территорий субъектов Российской Федерации, которым могут соответствовать региональные группы кандидатов на выборах депутатов Государственной Думы Федерального Собрания Российской Федерации шестого созыва» // Рос. газ. 2011. 17 августа. 
демократическая партия России, ПАТРИОТЫ РОССИИ, Коммунистическая партия Российской Федерации, Российская объединенная демократическая партия «ЯБЛОКО», Всероссийская политическая партия «ЕДИНАЯ РОССИЯ» и Всероссийская политическая партия «ПРАВОЕ ДЕЛО»1.

В федеральном списке кандидатов политической партии «Справедливая Россия» было 576 кандидатов, общефедеральная часть списка включала 8 кандидатов и 73 региональные группы. В составе Республики Башкортостан и Республики Татарстан Справедливая Россия выделила по 2 региональные группы, по 3 региональные группы были образованы в составе Краснодарского края, Московской области и города федерального значения Москва. Голоса избирателей, проживающих за пределами территории Российской Федерации, были отнесены к региональной группе «Калининградская область, Псковская область».

Список Либерально-демократической партии России состоял из 307 кандидатов, в том числе 10 кандидатов в общефедеральной части списка и 292 кандидата в составе 82 региональных групп. 2 региональные группы были образованы в Республиках Башкортостан, Дагестан, Татарстан, Краснодарском крае, Московской, Свердловской и Челябинской областях, 3 региональные группы в составе Ростовской области и 4 в составе города Москвы. Голоса избирателей, проживающих за пределами территории Российской Федерации, были отнесены к региональной группе «Псковская область».

В зарегистрированном ЦИК России федеральном списке кандидатов политической партии «ПАТРИОТЫ РОССИИ» было 298 фамилий, в том числе 10 - в общефедеральной части списка и 288 - в составе 83 региональных групп ${ }^{2} .2$ региональные группы были образованы в составе Челябинской области и 3 региональные группы в Волгоградской области. Голоса избирателей, проживающих за пределами территории Российской Федерации, были отнесены к региональной группе «Республика Северная Осетия - Алания».

По сравнению с выборами депутатов Государственной Думы пятого созыва, Коммунистическая партия Российской Федерации расширила свой партийный список ${ }^{3}$. Список Коммунистической партии Российской Федерации включал 590 кандидатов, в том числе 10 кандидатов в общефедеральной части списка и 580 - в 73 региональных группах. 2 региональные группы были сформированы в Республиках Башкортостан, и Татарстан, а также в Нижегородской и Свердловской областях. Как и у ПАТРИОТОВ РОССИИ, голоса избирателей, проживающих за пределами

${ }^{1}$ Федеральные списки кандидатов в депутаты Государственной Думы Федерального Собрания Российской Федерации шестого созыва, выдвинутые политическими партиями и зарегистрированные Центральной избирательной комиссией Российской Федерации. Специальный информационный выпуск ЦИК РФ // Рос. газ. 2011. 4 декабря. 200 с.

2 По сравнению с федеральными выборами 2007 года, список политической партии «Патриоты России» уменьшился с 433 до 298 кандидатов.

${ }^{3}$ На выборах 2007 года партия выдвинула 514 кандидатов. 
территории Российской Федерации, были отнесены КПРФ к региональной группе «Республика Северная Осетия - Алания».

Федеральный список Российской объединенной демократической партии «Яблоко» состоял из 10 кандидатов в общефедеральной части списка и 350 кандидатов в 78 региональных группах. В составе Республики Дагестан, Воронежской, Московской, Омской и Оренбургской областей Яблоко выделила 2 региональные группы, в Республике Башкортостан - 4 региональные группы, в городах федерального значения Москва и СанктПетербург - по 5 региональных групп. $\mathrm{K}$ региональной группе «Новосибирская область, Томская область» были отнесены поданные за федеральный список кандидатов голоса избирателей, проживающих за пределами территории Российской Федерации.

Как и на предыдущих выборах, Всероссийская политическая партия «Единая Россия» зарегистрировала самый многочисленный федеральный список из 597 фамилий. В общефедеральную часть списка был включен 1 кандидат - Президент Российской Федерации Медведев Д.А. 596 кандидатов были включены в состав 80 региональных групп.

Региональные группы «Единой России», как и на предыдущих федеральных выборах, возглавлялись высшими должностными лицами субъектов Российской Федерации (главами республик, губернаторами, главами администраций), депутатами Государственной Думы Федерального Собрания Российской Федерации, депутатами законодательных органов государственной власти субъектов Российской Федерации, руководящими должностными лицами Правительства Российской Федерации или федеральными министрами ${ }^{1}$.

В отличие от остальных политических партий, «ЕДИНАЯ РОССИЯ» не образовывала в одном субъекте Российской Федерации несколько региональных групп. Как и на федеральных выборах 2007 года, голоса избирателей, проживающих за пределами территории Российской Федерации, были отнесены партией к региональной группе «Калининградская область».

В федеральном списке кандидатов Всероссийской политической партии «ПРАВОЕ ДЕЛО» было 576 кандидатов, общефедеральная часть списка включала 10 кандидатов и 77 региональных групп. В составе Республики Башкортостан, Республики Татарстан и Ростовской области «ПРАВОЕ ДЕЛО» выделила по 2 региональные группы, 3 региональные группы были образованы в составе города федерального значения Москва. Голоса избирателей, проживающих за пределами территории Российской

${ }^{1}$ Во главе региональных групп зарегистрированного списка Единой России было 52 высших должностных лица субъектов Российской Федерации, 12 депутатов Государственной Думы Федерального Собрания Российской Федерации, 3 депутата законодательных органов государственной власти субъектов Российской Федерации, 6 руководящих должностных лиц Правительства Российской Федерации, 2 федеральных министра. 
Федерации, были отнесены к региональной группе «Калининградская область».

С позиций качества депутатского корпуса, «чистоты» народных представителей юридически значимыми представляются имеющиеся в федеральных партийных списках и документах избирательных комиссий:

- сведения кандидатов об источниках доходов, вкладах в банках, ценных бумагах и имуществе на праве собственности (в том числе, за пределами территории России), выявленные факты недостоверности поданных кандидатами сведений о доходах и имуществе;

- сведения об имеющихся у кандидатов судимостях (в том числе снятых и погашенных), выявленные факты сокрытия кандидатами сведений о неснятых (непогашенных) судимостях;

- сведения о наличии у кандидатов гражданства иностранного государства либо вида на жительство на территории иностранного государства, выявленные факты сокрытия кандидатами сведений о наличии гражданства иностранного государства либо вида на жительство на территории иностранного государства;

- сведения кандидатов об образовании, выявленные факты недостоверности поданных кандидатами сведений об образовании.

В рамках данного исследования автором проведен анализ соответствующих сведений о кандидатах, выдвинутых политическими партиями, принимавшими участие в выборах депутатов Государственной Думы Федерального Собрания Российской Федерации пятого и шестого созывов ${ }^{1}$.

В списке Коммунистической партии Российской Федерации на выборах депутатов Государственной Думы Федерального Собрания Российской Федерации пятого созыва отсутствовали сведения об источниках доходов, вкладах в банках, ценных бумагах и имуществе на праве собственности в отношении двух кандидатов: соискателе кафедры журналистики МГУ Сабировой Каметы Якубовны и временно неработающем, члене Комитета Дагестанского республиканского отделения Гаписове Ильгаме Исабековиче 2 .

У СПРАВЕДЛИВОЙ РОССИИ никаких сведений о доходах и имуществе не представили студент МАИ Ламанов Максим Олегович, а также временно неработающие Кузнецов Иван Сергеевич и Ткач Владимир Иванович ${ }^{3}$. Кандидат СПРАВЕДЛИВОЙ РОССИИ Петров Сергей Анатольевич владел 44\% акций Rolf Immobilien $\mathrm{GmbH}$ (Австрия), 50\% акций

${ }^{1}$ В двух электоральных циклах федеральных выборов 2007 и 2011 гг. участвовали «Коммунистическая партия Российской Федерации», «СПРАВЕДЛИВАЯ РОССИЯ», «Либерально-демократическая партия России», «ЕДИНАЯ РОССИЯ», Российская объединенная демократическая партия «ЯБЛОКО» и «ПАТРИОТЫ РОССИИ». Списки этих партий, главным образом, и являются предметом сравнительного исследования.

2 Сведения о размере и об источниках доходов, имуществе, принадлежащем кандидатам на праве собственности, о вкладах в банках, ценных бумагах (на основании данных, представленных кандидатами) // Рос. газ. 2007. 2 декабря. С. 120.

${ }^{3}$ Там же. С. $151,154$. 
Rolf Immobilien Verwaltungs GmbH, получал доходы от акций Latweiv Ltd (Кипр $)^{1}$.

В зарегистрированном федеральном списке Либеральнодемократической партии России отсутствовали сведения о доходах и имуществе временно неработающего Павлова Владимира Васильевича, врача-невролога ООО «Медилюкс-ТМ» Айгумовой Наиды Айгумовны, помощника адвоката Краснодарской краевой коллегии адвокатов, заместителя координатора по работе с молодежью Краснодарского регионального отделения ЛДПР Кропачева Александра Сергеевича, генерального директора ЗАО «Инстав», депутата Государственной Думы Ставропольского края на непостоянной основе Гасанова Джамаладина Набиевича $^{2}$. У временно неработающего, координатора Бийского местного отделения Алтайского регионального отделения ЛДПР Абрамова Сергея Владимировича в Сбербанке хранилось 17 рублей 15 копеек ${ }^{3}$.

Вызывает вопрос достоверность сведений об источниках доходов, вкладах в банках, ценных бумагах и имуществе на праве собственности ректора АНО ВПО «Институт мировых цивилизаций» Брюханова Владимира Александровича, который при общем доходе в 440 тысяч рублей приобрел в собственность жилые дома во Владимирской, Курской и Челябинской областях, квартиры в Республике Саха, Ставропольском и Камчатском краях, Архангельской, Белгородской, Владимирской, Вологодской, Ивановской, Иркутской, Кемеровской, Курганской, Московской, Новосибирской, Томской, Тульской, Челябинской, Читинской областях и городе Москве 4

В списке «ЕДИНОЙ РОССИИ» отсутствовали сведения о доходах и имуществе заместителя генерального директора ООО «Балтстройсервис», члена Регионального политического совета Санкт-Петербургского регионального отделения партии Воробьева Ивана Валерьевича ${ }^{5}$.

Депутат Государственной Думы Федерального Собрания Российской Федерации, член Комитета Государственной Думы по промышленности, строительству и наукоемким технологиям Скоч Андрей Владимирович при выдвижении и регистрации на федеральных выборах 2007 года владел $100 \%$ акций Pokolenie Ltd (Соединенное Королевство)

Депутат Государственной Думы Федерального Собрания Российской Федерации, член Комитета Государственной Думы по безопасности Аршба Отари Ионович являлся собственником земельных участков в Республике Грузия площадью 702 кв.м и 1428 кв.м, а также жилого дома в Республике Грузия площадью 242 кв.м

\footnotetext{
${ }^{1}$ Там же. С. 151.

${ }^{2}$ Там же. С. 139, 140, 142.

${ }^{3}$ Там же. С. 138.

${ }^{4}$ Там же. С. 138.

5 Там же. С. 174

${ }^{6}$ Там же. С. 166.

${ }^{7}$ Там же. С. 168.
} 
Депутат Государственной Думы Федерального Собрания Российской Федерации, заместитель Председателя Комитета Государственной Думы по природным ресурсам и природопользованию Тимченко Вячеслав Степанович владел 50\% акций ООО «Интер-Вена» (Республика Чехия) ${ }^{1}$.

Депутат Государственной Думы Федерального Собрания Российской Федерации, Председатель Комитета Государственной Думы по кредитным организациям и финансовым рынкам Резник Владислав Матусович с общим доходом 1млрд. 162 млн. 942 тыс. 60 рублей имел вклады в банках Caja de Ahorros y Pensiones de Barselona (Испания) UBS AG (Швейцария) в размере 21 млн. 446 тыс. 149 рублей 31 коп. и 420 млн. 982 тыс. 247 рублей 55 коп соответственно 2 .

Список партии «ПАТРИОТЫ РОССИИ» на федеральных выборах 2007 года имел максимальное количество кандидатов, не предоставивших сведения об источниках доходов, вкладах в банках, ценных бумагах и имуществе на праве собственности. В их числе: третье лицо в федеральной части списка, руководитель управления АНО «Центр защиты экономических и социальных прав граждан» Маховиков Сергей Анатольевич, директор по строительству ООО «Стройкомплектснаб» Жураковский Александр Витальевич, коммерческий директор Фонда культуры Республики Северная Осетия - Алания Кулов Урузмаг Асланбекович, Председатель комитета Ставропольского регионального отделения партии Козлитин Сергей Петрович, начальник отдела службы охраны ООО «СтройМонтажРеконструкция» Якушев Айрат Рифкатович, директор экономического Департамента ООО «Инвестпродукт», депутат Хабаровской городской Думы на непостоянной основе Кондракова Светлана Михайловна, президент Фонда помощи социально незащищенным семьям населения «Горячев-Фонд», депутат Законодательного Собрания Ульяновской области на непостоянной основе Горячев Олег Юрьевич, генеральный директор ООО «2С групп» Мелашенко Сергей Петрович, директор ООО «НикА» Горбунова Алла Дмитриевна, директор ООО «Аргон», депутат Братской городской Думы на непостоянной основе Трушников Александр Петрович, врачстоматолог Центра семейной стоматологии «Легкое дыхание» Абдуллатипов Габиб Абдуллатипович, а также пенсионер Мазур Николай Петрович и временно неработающий Горокоев Идрис Султанович ${ }^{3}$. Инструктор по боевому искусству «Федерации Сюриндзи Будо кэмпо» Грибакин Игорь Михайлович указал вклад в Сбербанке России в размере 5 рублей, а домохозяйка Жуган Алла Петровна - вклад в Сбербанке в размере 17 рублей 24 копейки ${ }^{4}$. У адвоката Кушны Олега Анатольевича общий доход составил 7 тыс. рублей 5 .

\footnotetext{
${ }^{1}$ Там же. С. 172.

${ }^{2}$ Там же. С. 174.

${ }^{3}$ Там же. С. $155,156,157,160,161$.

${ }^{4}$ Там же. С. $158,159$.

${ }^{5}$ Там же. С. 157.
} 
В списке партии «ЯБЛОКО» на выборах депутатов Государственной Думы Федерального Собрания Российской Федерации пятого созыва отсутствовали сведения об источниках доходов, вкладах в банках, ценных бумагах и имуществе на праве собственности в отношении двух кандидатов: временно неработающего, Председателя Мордовского регионального отделения партии Гридина Владимира Евгеньевича, а также студента ФГОУ ВПО «Костромская государственная сельско-хозяйственная Академия» Морозова Олега Сергеевича ${ }^{1}$. Вместе с тем, кандидат Халимов Насардин Хамзатович утаил сведения или забыл о двух магазинах в Ярославской области, земельных участках в Ярославской области размером 1259 кв.м и 732 кв.м, торговых площадях в здании торгового комплекса размером 202, 2 кв.м и 225 кв.м². Конашенков Александр Алексеевич не сообщил о 18 земельных участках в Псковской области общей площадью 1 млн. 31 тыс. 395 кв. ${ }^{3}$.

Сравним данные 2007 года со сведениями об источниках доходов, вкладах в банках, ценных бумагах и имуществе на праве собственности (в том числе, за пределами территории России), представленными кандидатами на федеральных выборах 2011 года.

Ряд кандидатов из федерального списка политической партии СПРАВЕДЛИВАЯ РОССИЯ на выборах депутатов Государственной Думы Федерального Собрания Российской Федерации шестого созыва не имел никаких источников доходов, вкладов в банках, ценных бумаг и имущества на праве собственности. В качестве примера можно привести депутата, Заместителя Председателя комитета Народного Собрания Республики Дагестан по делам молодежи, спорту и туризму Пайзулаева Мурата Магомедовича, заместителя генерального директора ООО «Регионгазлизинг», депутата Законодательного Собрания Пермского края на непостоянной основе Луканина Алексея Александровича, Секретаря Бюро Совета регионального отделения в Пермском крае Бурлякова Юрия Васильевича, генерального директора ООО «Корпорация «Гринвич», депутата Законодательного Собрания Пермского края на непостоянной основе Маркова Андрея Анатольевича, домохозяина Морозова Станислава Андреевича ${ }^{4}$. Красиков Александр Александрович посчитал возможным указать только вклад в размере 138 рублей в ОАО «Сбербанк России» и 2245

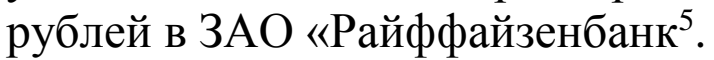

У Либерально-демократической партии России также присутствовали «малоимущие» и «бездомные» кандидаты, например, Софронов Дмитрий Валерьевич, Польской Денис Александрович, Любченко Дмитрий

${ }^{1}$ Там же. С. 175, 177.

2 Там же. С. 208.

${ }^{3}$ Там же. С. 208.

4 Сведения о размере и об источниках доходов, имуществе, принадлежащем кандидатам на праве собственности, о вкладах в банках, ценных бумагах (на основании данных, представленных кандидатами) // Рос. газ. 2011. 4 декабря. С. 94, 97, 110.

${ }^{5}$ Там же. С. 108. 
Аркадьевич, Хагаев Аслан Султанович, Лозицкая Маргарита Леонидовна ${ }^{1}$. Никаких источников доходов, вкладов в банках, ценных бумаг и имущества на праве собственности не имели аспирант ФГОУ ВПО «КабардиноБалкарская сельскохозяйственная академия им. В.М. Кокова» Уначев Заур Аликович, мастер ООО «Брянскжелдорремсервис» Михаленков Александр Валерьевич, студент ГОУ ВПО «Курганский государственный университет» Егоров Никита Олегович, заместитель директора по экономическим вопросам ООО «Бойко-Сервис», депутат Совета Москаленского муниципального района Омской области на непостоянной основе Борисенко Дмитрий Васильевич, помощник ректора НОУ ВПО «МИУС» Худяков Роман Иванович ${ }^{2}$.

По сравнению с зарегистрированным списком на федеральных выборах 2007 года, в списке партии «ПАТРИОТЫ РОССИИ» заметно сократилось число кандидатов, не предоставивших сведения об источниках доходов, вкладах в банках, ценных бумагах и имуществе на праве собственности. У временно неработающих Мальсагова Алаудина Ахметовича и Эдильсултанова Хамзата Махмудовича, директора ООО «БСД-групп» Бражина Павла Анатольевича, торгового представителя ООО «КДВ Групп» Сорокина Дмитрия Владимировича нет никакой собственности, кроме автомобиля ${ }^{3}$. Никаких сведений о размере и об источниках доходов не указал только менеджер по продажам Смоляр Алексей Николаевич4

В тоже время Альжанов Бахаджан Бахриденович не упомянул о благоустроенной промплощади 1295,20 кв.м (по наружному обмеру) и тепловых сетях (544, 4 кв.м) в г. Омске, а также о транспортных средствах: ГАЗ 3302 (2005), ГАЗ 3302 (2006), ЗИЛ 431412 (2006), ЗИЛ 431410 (2006), ГАЗ 3302 (2006), ГАЗ 3302 (2006), Mitsubishi Canter (2009), ГАЗ 330210 (2003), КАМАЗ 5320 (2004), АФ 47821А (2011), ЗИЛ 431410 (2006), ГАЗ 3302 (2004), ЗИЛ ММЗ 554 (2011), КАМАЗ 53212 (2011), ГАЗ 3302 (2004), ЗИЛ 433360 (2010), ЗИЛ 433360 (2010), 2775-01 (2009), 270710 (2009), 270701 (2009), ГАЗ 3302 (2007), ЗИЛ 433362 (2004), ЗИЛ 433362 (2007), ЗИЛ 5301Б0 (2007), ЗИЛ 5301Б0 (2007), 27901-000010-21 (2009), ЗИЛ 130 (2009), КАМАЗ 5320 (2008), ЗИЛ 431412 (2010) и ГАЗ $3302(2006)^{5}$.

В отличие от федеральных выборов 2007 года, в федеральном списке кандидатов на выборах депутатов Государственной Думы Федерального Собрания Российской Федерации шестого созыва Коммунистической партии Российской Федерации кандидаты, не указавшие никаких сведений о размере и об источниках доходов, отсутствовали.

Однако кандидат Аргунов Олег Абубекирович «забыл» о четырех земельных участках в Карачаево-Черкесской Республике (10 000 кв.м; 648000 кв.м; 60000 кв.м; 1540 кв.м), земельном участке в Ставропольском

\footnotetext{
${ }^{1}$ Там же. С. $111,112,113,114$.

2 Там же. С. $111,114,115,116$.

${ }^{3}$ Там же. С. $118,119,120,123$.

${ }^{4}$ Там же. С. 118.

${ }^{5}$ Там же. С. 192.
} 
крае (600 кв.м) и жилом объекте (33,8 кв.м) в Карачаево-Черкесской Республике ${ }^{1}$. Валеев Виктор Семенович не указал три земельных участка в Ханты-Мансийском автономном округе (1 231 кв.м; 900 кв.м; 28 кв.м), две квартиры в Тюменской области (167 кв.м и 76,9 кв.м), часть жилого дома (83,9 кв.м), жилое помещение (42,7 кв.м), три здания (строения) в ХантыМансийском автономном округе (26 кв.м; 48 кв.м; 28 кв.м) и три здания в Тюменской области (48,3 кв.м; 192,7 кв.м; 31,2 кв.м) $)^{2}$. Горбунов Владимир Васильевич не указал нежилые помещения в Краснодарском крае (5 кв.м; 109, 7 кв.м; 38 кв.м; 53,4 кв.м; 681,6 кв.м; 15,8 кв.м; 241, 7 кв.м; 37, 6 кв.м; 39, 7 кв.м; 99,1 кв.м; 38, 5 кв.м; 107,9 кв.м; 31, 7 кв.м; 83, 6 кв.м; 101, 5 кв.м; 38, 2 кв.м; 38, 8 кв.м; 105, 3 кв.м; 101, 9 кв.м; 36, 5 кв.м; 298, 5 кв.м; 36, 4 кв.м; 38, 2 кв.м; 102, 5 кв.м; 36, 6 кв.м; 155, 7 кв.м; 36.9 кв.м; 102, 1 кв.м; 37, 4 кв.м; 36, 7 кв.м; 37, 1 кв.м; 365, 5 кв.м; 684, 8 кв.м; 209, 6 кв.м; 106, 2 кв.м ${ }^{3}$

В списке Российской объединенной демократической партии «ЯБЛОКО» нет сведений об имуществе, вкладах, ценных бумагах и источниках доходов заместителя Председателя Кабардино-Балкарского регионального отделения Будаева Назира Мустафаевича, заместителя Председателя Ростовского регионального отделения Мусиенко Александра Анатольевича и генерального директора ООО «Мобильное выставочное оборудование» Прочика Евгения Евгеньевича ${ }^{4}$.

В списке Всероссийской политической партии «ЕДИНАЯ РОССИЯ», как и у Коммунистической партии Российской Федерации, кандидатов, не указавших никаких сведений о размере и об источниках доходов, не было.

Кандидат «ЕДИНОЙ РОССИИ», генеральный директор ООО «Инвестиционная финансовая компания «Метрополь», депутат Совета депутатов муниципального образования «Еравнинский район» Республики Бурятия на непостоянной основе Слипенчук Михаил Викторович, является собственником земельных участков в Демократической Республике Конго размером 1200 и 1349 кв.м., жилых домов в Демократической Республике Конго площадью в 500 и 600 кв.м., квартиры во Франции, имеет вклады в банках J.P.Morgan (Suisse) - 18 млн. 521 тыс. 898 рублей, BNP Paribas France Cannes - 9 млн. 304 тыс. 219 рублей, BNP Paribas Private Bank Monako - 11 млн. 845 тыс. 216 рублей, владеет 2 тыс. акций Mining Bank of Kongo Sarl, 100 акциями корпорации IFC Metropol Canada Inc ${ }^{5}$.

Вызывает сомнение достоверность сведений об источниках доходов, вкладах в банках, ценных бумагах и имуществе на праве собственности президента ООО «Новые технологии» Николаевой Елены Леонидовны, которая при общем доходе в 408 тысяч рублей имеет в собственности земельные участки в Московской области (1221 кв.м - совместная собственность), жилой дом в Московской области (284,9 кв.м - совместная

\footnotetext{
${ }^{1}$ Там же. С. 195.

2 Там же. С. 195.

${ }^{3}$ Там же. С. 195.

${ }^{4}$ Там же. C. $139,144,145$.

${ }^{5}$ Там же. С. 147.
} 
собственность), квартиру в $\quad$ г. Москва (92,9 кв.м - совместная собственность), легковые автомобили «Ламборгини диабло» (1994 г.), БМВ 540 (1998 г.), вклады в банках: ОАО «АКБ «Росевробанк» - 679 тыс. 195 рублей 12 копеек; акции ООО «Ка-Фур» - 80\%, ООО «Компания КаскадВиа» - 100\%, ООО «Каскад ВИА-М» - 100\%, ЗАО «Брэйн и К» - 1320 акций, ООО «Кирпичный завод «Понежукайский» (Адыгея) - 60\%, ООО «Недра Кубани» - 50\%, ООО «Твой Новый Дом» - 51\%, ООО «Золотой крендель» $100 \%$, ООО «Логистическая компания» - 100\%, ООО «ЕвроИндустрия» $100 \%$, ООО «Профессиональная Информация» - 100\%, ООО «Комбинат нерудных материалов «Теучежский» - 50\%, 3АО «Компания Пластика» - 80 акций, ООО «К-Финанс» - 100\%, ООО «ЛонгЛайф» - 70\%, ООО «ТехРечФлот» - 2\%, ЗАО «Хоббит» - 450 тыс. акций, ЗАО «ПрофильСервис» - 75 акций, ЗАО «Лэми» - 325 акций, ООО «Астер-М»- 100\%, ООО «Диамант»- 50\%, ООО «Новые Технологии» - 70\%, ООО «К-Фикс Консалт» - 100\%, OОО «ТST- групп» - 100\%, ООО «Профпласт-Екатеринбург» - 100 $\% .1$

У Всероссийской политической партии «ПРАВОЕ ДЕЛО», кроме временно неработающего Ярославцева Алексея Рафгатовича и студента НОУ ВПО «Московский институт права» Евтюшина Александра Александровича, сведения о размере и об источниках доходов, вкладах в банках, ценных бумагах и имуществе на праве собственности не представили Председатель регионального отделения партии в Ненецком автономном округе Малышев Максим Васильевич, юрист ООО «Корпорация «Независимые юристы» Дворецкий Игорь Александрович, Председатель исполнительного комитета Орловского регионального отделения партии Вакутин Павел Александрович и индивидуальный предприниматель, член Политического Совета регионального отделения в Костромской области Алексеев Александр Валерьевич ${ }^{2}$.

Кандидат партии «ПРАВОЕ ДЕЛО» Богрянцев Андрей Евгеньевич не сообщил о принадлежащем ему жилом помещении в г. Краснодар площадью 64,4 кв.м, а также о нежилых помещениях в г. Сочи площадью 938,9 кв.м (доля в праве 1/3), 362,5 кв.м (доля в праве 1/3), 2854 кв.м (доля в праве 1/3) и $1320,6$ кв.м (доля в праве $1 / 3)^{3}$.

Гусева Светлана Валериановна не упомянула о 3-х комнатной квартире (67,27 кв.м), 2-х комнатной (42,7 кв.м) и 1-комнатной (40,5 кв.м) квартирах в г. Кострома ${ }^{4}$.

Кандидат Исаев Роман Харонович «забыл» о принадлежащем ему подъезде к г. Элиста от автодороги М-6 «Каспий», жилых помещениях в г. Элиста площадью 89 кв.м и 151,2 кв.м, производственных помещениях в г. Элиста (224,63 кв.м, 292,49 кв.м и 365,3 кв.м), нежилых помещениях в г.

\footnotetext{
${ }^{1}$ Там же. С. 161.

2 Там же. С. $172,175,176,178$.

${ }^{3}$ Там же. С. 200.

${ }^{4}$ Там же. С. 200.
} 
Элиста (318,39 кв.м, 292,75 кв.м, 24,24 кв.м, 1711,7 кв.м, 19,5 кв.м), землях населенных пунктов в г. Элиста (3384 кв.м, 4428 кв.м, 4024 кв.м, 1828 кв.м, 946 кв.м, 18456 кв.м, 421 кв.м, 2306 кв.м $)^{1}$.

Плитарак Владимир Сергеевич не сообщил о земельных участках в д. Крупшево Калининского района Тверской области площадью 24000 кв.м, 41000 кв.м, 75000 кв.м, 66000 кв.м, 60390 кв.м и 61935 кв.м².

Мавлиев Рафил Назифович не упомянул о принадлежащей ему барже 3985 ББ 2004 года ${ }^{3}$.

Даурбеков Иса Заурбекович не сообщил о доходах, полученных от филиала корпорации «Ворлд Вижн Интернешнл» (США) в России в размере 193 тыс. 554 рубля 4 .

Отдельного рассмотрения требует вопрос об имеющихся у кандидатов судимостях (в том числе снятых и погашенных), а также выявленных фактах сокрытия кандидатами сведений о неснятых (непогашенных) судимостях ${ }^{5}$.

Самым «грязным» в криминальном отношении был федеральный список кандидатов политической партии СПРАВЕДЛИВАЯ РОССИЯ. В указанном федеральном списке в численном отношении по сравнению со списками других политических партий, участвовавших в федеральных выборах 2011 года, содержалось наибольшее количество кандидатов в депутаты, подвергавшихся уголовному преследованию и имеющих погашенные судимости.

Из выдвинутого политической партией СПРАВЕДЛИВАЯ РОССИЯ федерального списка кандидатов в депутаты Государственной Думы Федерального Собрания Российской Федерации шестого созыва до регистрации было исключено трое кандидатов с криминальным прошлым.

В зарегистрированном списке партии СПРАВЕДЛИВАЯ РОССИЯ осталось 46 кандидатов, привлекавшихся к уголовной ответственности, в том числе 10 с погашенными и 1 с непогашенной судимостью 6 .

3 кандидата были осуждены за совершение преступлений против свободы, чести и достоинства личности («клевета»), 3 кандидата - за совершение преступлений против общественной безопасности (двое за хулиганство, один за незаконное ношение, хранение, приобретение, изготовление или сбыт оружия, боевых припасов или взрывчатых веществ), 3

${ }^{1}$ Там же. С. 200.

2 Там же. С. 200.

3 Там же. С. 200.

${ }^{4}$ Там же. С. 199.

${ }^{5}$ Необходимо сделать оговорку, что ряд представителей уголовной среды не имеет (не имел) судимостей. Кроме того, для проникновения в федеральный и региональные органы законодательной власти криминальными элементами используется смена фамилий, удаление своих персональных данных из региональных баз правоохранительных органов, а также продвижение «незасвеченных» ставленников (нередко близких родственников), не имеющих судимостей и выявленных связей с организованной преступностью.

${ }^{6}$ Неснятую судимость по ч.2 ст. 129 УК РФ указал один кандидат (региональная группа № 30). 
- за преступления в сфере экономической деятельности («незаконное предпринимательство»), 2 - за преступления против порядка управления («оскорбление представителя власти» и «подделка, изготовление или сбыт поддельных документов, государственных наград, штампов, печатей, бланков»), 1 - за совершение преступления против конституционных прав и свобод человека и гражданина («нарушение изобретательских и патентных прав»).

Из числа лиц, имеющих погашенные судимости, четверо - депутаты законодательных органов государственной власти субъектов Российской Федерации и представительных органов муниципальных образований, один является главой муниципального образования, трое - председатели советов местных отделений партии, один - председатель первичного отделения партии. 4 осужденных были освобождены от наказания постановлением Государственной Думы Федерального Собрания Российской Федерации об объявлении амнистии.

В отношении 6 кандидатов, подвергавшихся уголовному преследованию (среди них 4 депутата), уголовные дела были прекращены по п.3 ст. 24 УПК РФ в связи с истечением сроков давности уголовного преследования, причем один из кандидатов (депутат законодательного органа государственной власти субъекта Российской Федерации на непостоянной основе) в 2008 г. привлекался к уголовной ответственности по ч.1 ст.141 УК РФ («Воспрепятствование осуществлению избирательных прав или работе избирательных комиссий»).

В отношении 5 кандидатов (один из них депутат) уголовные дела были прекращены по ст. 25 УПК РФ в связи с примирением сторон или по ст. 9 УПК РСФСР в связи с примирением с потерпевшим. В отношении 5 кандидатов (из них двое - депутаты) уголовные дела были прекращены вследствие акта об амнистии (пп.3 п.1 ст. 27 УПК РФ и п.4 ст.5 УПК РСФСР), в отношении 5 (трое - депутаты) - в связи с деятельным раскаянием (ст. 28 УПК РФ). Один из кандидатов (депутат Государственной Думы Федерального Собрания Российской Федерации) находится в федеральном розыске (мера пресечения - арест), в отношении другого кандидата (депутат муниципального собрания на непостоянной основе) розыск был прекращен в январе 2010 года. По двум кандидатам ведется следствие.

Из выдвинутого политической партией «Коммунистическая партия Российской Федерации» федерального списка кандидатов в депутаты Государственной Думы Федерального Собрания Российской Федерации шестого созыва до регистрации было исключено два кандидата с криминальным прошлым.

В зарегистрированном списке партии «Коммунистическая партия Российской Федерации» осталось 37 кандидатов, привлекавшихся к уголовной ответственности, в том числе 11 с погашенными судимостями.

Один кандидат имел две судимости.

1 кандидат был осужден за совершение преступления против свободы, чести и достоинства личности («незаконное лишение свободы»), 4 кандидата 
- за совершение преступлений против собственности (один за кражу, один за грабеж и двое за мошенничество), 2 - за преступления в сфере экономической деятельности («уклонение от уплаты налогов и (или) сборов с организации», «незаконное предпринимательство»), 2 - за преступления против безопасности движения и эксплуатации транспорта, 1 - за совершение преступления против государственной власти, интересов государственной службы и службы в органах местного самоуправления («халатность»), 1 - за преступление против правосудия (незаконные действия в отношении имущества, подвергнутого описи или аресту либо подлежащего конфискации»).

Из числа лиц, имеющих погашенную судимость, четверо - депутаты законодательных органов государственной власти субъектов Российской Федерации и представительных органов муниципальных образований, один является первым секретарем городского отделения, один - первым секретарем районного отделения партии. 4 осужденных были освобождены от наказания постановлением Государственной Думы Федерального Собрания Российской Федерации об объявлении амнистии.

В отношении 3 кандидатов (среди них 1 депутат) уголовные дела были прекращены по п.3 ст. 24 УПК РФ в связи с истечением сроков давности уголовного преследования. В отношении 6 кандидатов (4 из них депутаты) уголовные дела были прекращены по ст. 25 УПК РФ в связи с примирением сторон или по ст. 9 УПК РСФСР в связи с примирением с потерпевшим. В отношении 2 кандидатов (один из них - секретарь комитета регионального отделения, другой - член бюро областного комитета) уголовные дела были прекращены вследствие акта об амнистии (пп.3 п.1 ст. 27 УПК РФ и п.4 ст.5 УПК РСФСР), в отношении 2 (один - первый секретарь комитета республиканского отделения) - в связи с деятельным раскаянием (ст. 28 УПК РФ).

В отношении двух кандидатов проводится предварительное следствие, в отношении одного из них избрана мера пресечения в виде заключения под стражу (ст. 98 УПК РФ).

Из выдвинутого политической партией «ЯБЛОКО» федерального списка кандидатов в депутаты Государственной Думы Федерального Собрания Российской Федерации шестого созыва до регистрации было исключено семь кандидатов с криминальным прошлым.

В зарегистрированном списке партии «ЯБЛОКО» осталось 16 кандидатов, привлекавшихся к уголовной ответственности, в том числе $10 \mathrm{c}$ погашенными судимостями и 1 с непогашенной судимостью ${ }^{1}$.

3 кандидата были осуждены за совершение преступлений против свободы, чести и достоинства личности («клевета», «оскорбление»), 2 кандидата - за совершение преступлений против собственности

${ }^{1}$ Непогашенную судимость по ч.3 ст. 129 УК РФ («клевета») указал один кандидат (региональная группа № 66). Судимость не погашена в связи с отказом осужденного выполнить решение суда. 
(«причинение имущественного ущерба путем обмана или злоупотребления доверием» и «хищение общественного имущества, совершенное путем мошенничества»), 2 - за преступления в сфере экономической деятельности («обман потребителя», «незаконное предпринимательство»), 2 - за преступления против безопасности движения и эксплуатации транспорта, 2 за совершение преступлений против государственной власти, интересов государственной службы и службы в органах местного самоуправления («дача взятки», «получение взятки»), 1 - за преступление против общественной безопасности, общественного порядка и здоровья населения («приобретение или сбыт имущества, заведомо добытого преступным путем»), 1 - за преступление против жизни и здоровья («побои») и 1 - за преступление против основ конституционного строя и безопасности государства («призывы к насильственному изменению конституционного строя») $)^{1}$.

Из числа лиц, имеющих судимость, один являлся депутатом представительного органа муниципального образования на непостоянной основе, два - председателями региональных отделений партии, один председателем местного отделения партии.

1 осужденный был освобожден от наказания постановлением Государственной Думы Федерального Собрания Российской Федерации об объявлении амнистии.

В отношении 1 кандидата, подвергавшегося уголовному преследованию (член Федерального Совета партии), уголовное дело было прекращено в связи с истечением сроков давности уголовного преследования. В отношении 1 кандидата (член Регионального Совета партии) уголовное дело было прекращено в связи с примирением сторон. В отношении 2 кандидатов уголовные дела были прекращены вследствие акта об амнистии (пп.3 п.1 ст. 27 УПК РФ и п.4 ст.5 УПК РСФСР), в отношении 2 (один - председатель регионального отделения партии) - в связи с деятельным раскаянием (ст. 28 УПК РФ).

В отношении двух кандидатов проводится предварительное следствие, в отношении одного из них (депутат представительного органа муниципального образования на непостоянной основе) избрана мера пресечения в виде заключения под стражу (ст. 98 УПК РФ).

Самыми «чистыми» в криминальном плане стали федеральные списки кандидатов, зарегистрированные политической партией «Либеральнодемократическая партия России» и Всероссийской политической партией «ЕДИНАЯ РОССИЯ»².

Из выдвинутого политической партией «Либерально-демократическая партия России» федерального списка кандидатов в депутаты

1 Некоторые кандидаты были осуждены по совокупности составов преступлений.

2 Зарегистрированные федеральные списки указанных партий содержали наименьшее число лиц, привлекавшихся к уголовной ответственности и имеющих погашенные судимости. 
Государственной Думы Федерального Собрания Российской Федерации шестого созыва до регистрации было исключено два кандидата с криминальным прошлым.

В зарегистрированном списке партии «Либерально-демократическая партия России» осталось 9 кандидатов, привлекавшихся к уголовной ответственности (двое из них - депутаты Государственной Думы Федерального Собрания Российской Федерации), в том числе 3 с погашенными судимостями.

1 кандидат был осужден за совершение преступления против общественной безопасности («хулиганство»), 1 кандидат - за преступление против жизни, здоровья, свободы и достоинства личности («изнасилование»), 1 кандидат - за преступление против правосудия («побег из места лишения свободы, из-под ареста или из-под стражи»).

Из числа лиц, имеющих погашенную судимость, один кандидат являлся депутатом Государственной Думы Федерального Собрания Российской Федерации, членом комитета Государственной Думы по безопасности.

В отношении 2 кандидатов, подвергавшихся уголовному преследованию (депутат законодательного органа государственной власти субъекта Российской Федерации и депутат представительного органа муниципального образования), уголовные дела были прекращены по ст. 25 УПК РФ в связи с примирением сторон или по ст. 9 УПК РСФСР в связи с примирением с потерпевшим. В отношении 1 кандидата (депутат законодательного органа государственной власти субъекта Российской Федерации) уголовное дело было прекращено в связи с деятельным раскаянием (ст. 28 УПК РФ).

Из выдвинутого Всероссийской политической партией «ЕДИНАЯ РОССИЯ» федерального списка кандидатов в депутаты Государственной Думы Федерального Собрания Российской Федерации шестого созыва до регистрации был исключен один кандидат с криминальным прошлым.

В зарегистрированном федеральном списке кандидатов в депутаты Государственной Думы Федерального Собрания Российской Федерации шестого созыва партии «ЕДИНАЯ РОССИЯ» осталось 10 кандидатов, привлекавшихся к уголовной ответственности, в том числе 2 ранее судимых.

1 кандидат был осужден за совершение преступления против общественной безопасности («незаконное ношение, хранение, приобретение, изготовление или сбыт оружия, боевых припасов или взрывчатых веществ»), 1 - за совершение преступления против конституционных прав и свобод человека и гражданина («нарушение правил охраны труда»).

В отношении 1 кандидата уголовное дело было прекращено в связи с истечением сроков давности уголовного преследования, в отношении 1 кандидата (депутат законодательного органа государственной власти субъекта Российской Федерации на непостоянной основе) - в связи с примирением сторон.

Из выдвинутого политической партией «ПАТРИОТЫ РОССИИ» федерального списка кандидатов в депутаты Государственной Думы 
Федерального Собрания Российской Федерации шестого созыва до регистрации было исключено девять кандидатов с криминальным прошлым.

В зарегистрированном списке партии «ПАТРИОТЫ РОССИИ» осталось 14 кандидатов, привлекавшихся к уголовной ответственности, в том числе 4 с погашенными судимостями.

1 кандидат был осужден за совершение преступления против жизни, здоровья, свободы и достоинства личности («умышленное менее тяжкое телесное повреждение»), 1 кандидат - за совершение преступления против собственности («умышленное уничтожение или повреждение имущества»), 1 - за преступление против безопасности движения и эксплуатации транспорта («нарушение правил безопасности движения и эксплуатации транспорта»), 1 - за совершение преступления против государственной власти, интересов государственной службы и службы в органах местного самоуправления («превышение должностных полномочий»).

Один кандидат имел неоднократные судимости.

В отношении 4 кандидатов, подвергавшихся уголовному преследованию, уголовные дела были прекращены по ст. 25 УПК РФ в связи с примирением сторон или по ст. 9 УПК РСФСР в связи с примирением с потерпевшим.

В отношении одного кандидата (депутат представительного органа муниципального образования) уголовное дело находится на стадии судебного разбирательства.

Из выдвинутого Всероссийской политической партией «ПРАВОЕ ДЕЛО» федерального списка кандидатов в депутаты Государственной Думы Федерального Собрания Российской Федерации шестого созыва до регистрации было исключено десять кандидатов с криминальным прошлым.

В зарегистрированном федеральном списке кандидатов в депутаты Государственной Думы Федерального Собрания Российской Федерации шестого созыва партии «ПРАВОЕ ДЕЛО» осталось 23 кандидата, привлекавшихся к уголовной ответственности, в том числе 6 имеющих погашенную судимость.

2 кандидата были осуждены за совершение преступлений против свободы, чести и достоинства личности («клевета»), 2 кандидата - за совершение преступлений против собственности («мошенничество» и «присвоение или растрата»), 1 - за преступление против здоровья населения и общественной нравственности («незаконные приобретение, хранение, перевозка, изготовление, переработка наркотических средств, психотропных веществ или их аналогов, а также незаконные приобретение, хранение, перевозка растений, содержащих наркотические средства или психотропные вещества, либо их частей, содержащих наркотические вещества или психотропные вещества»), 1 - за совершение преступления против государственной власти, интересов государственной службы и службы в органах местного самоуправления («превышение должностных полномочий»).

Из числа лиц, имеющих погашенную судимость, один кандидат являлся депутатом представительного органа муниципального образования на 
непостоянной основе, два - членами политического совета региональных отделений партии.

В отношении 1 кандидата (член политического совета регионального отделения партии), уголовное дело было прекращено в связи с истечением сроков давности уголовного преследования. В отношении 3 кандидатов (двое из них - председатели местных отделений партии) уголовные дела были прекращены в связи с примирением сторон. В отношении 3 кандидатов (один из них - член политического совета регионального отделения партии) уголовные дела были прекращены вследствие акта об амнистии (пп.3 п.1 ст. 27 УПК РФ и п.4 ст.5 УПК РСФСР), в отношении 1 (председатель регионального отделения партии) - в связи с деятельным раскаянием (ст. 28 УПК РФ).

В отношении 1 кандидата в депутаты Государственной Думы проводится предварительное следствие, в отношении 1 кандидата уголовное дело направлено в суд, в отношении 1 кандидата ведется дополнительное расследование по уголовному делу.

По результатам проведенных выборов депутатские мандаты были распределены между 4 политическими партиями. Всероссийская политическая партия «ЕДИНАЯ РОССИЯ» получила 238 депутатских мест в парламенте, Политическая партия «Коммунистическая партия Российской Федерации» - 92, Политическая партия СПРАВЕДЛИВАЯ РОССИЯ - 64, Политическая партия «Либерально-демократическая партия России» - 56 1 .

В списке избранных депутатов Государственной Думы Федерального Собрания Российской Федерации шестого созыва 9 депутатов привлекались к уголовной ответственности, 2 - имеют погашенные судимости ${ }^{2}$.

Сравнительный анализ результатов выборов депутатов Государственной Думы Федерального Собрания Российской Федерации пятого и шестого созывов ставит перед нами насущные вопросы. Могут ли лица, привлекавшиеся к уголовной ответственности, работать в комитете Государственной Думы Федерального Собрания Российской Федерации по гражданскому, уголовному, арбитражному и процессуальному законодательству? Могут ли лица, имеющие недвижимое имущество за пределами территории Российской Федерации, или имеющие судимость, быть депутатами Государственной Думы и при этом работать в комитете Государственной Думы по безопасности? Могут ли лица, привлекавшиеся к уголовной ответственности за совершение преступлений против собственности, работать в комитете Государственной Думы по экономической политике и предпринимательству? Могут являться депутатами Государственной Думы, членами комитета Государственной

${ }^{1}$ Постановление ЦИК России от 9 декабря 2011 года № 70/576-6 «О результатах выборов депутатов Государственной Думы Федерального Собрания Российской Федерации шестого созыва» // Рос. газ. 2011. 10 декабря.

${ }^{2}$ В списке избранных депутатов Государственной Думы Федерального Собрания Российской Федерации пятого созыва 8 депутатов привлекались к уголовной ответственности, 2 - имели погашенные судимости. 
Думы по безопасности граждане-фигуранты уголовных дел, в чьих квартирах правоохранительные органы в ходе оперативно-розыскной деятельности обнаруживали автоматы без номеров с глушителями, магазины, сотни патронов и гранаты РГД-5?

Ответ однозначный - нет.

Некоторые ранее судимые кандидаты искажают установочные данные (отчества, дату рождения) или баллотируются в составе региональных групп субъектов Российской Федерации, где они не проживали и к которым они не имеют никакого отношения. Часть кандидатов оперативно меняет партийную принадлежность и баллотируется в списках другой партии (например, попадают из выдвинутых списков «Яблока» в списки партии «Патриоты России»).

Указание в качестве рода занятий «временно неработающий» иногда используется кандидатами, в отношении которых избрана мера пресечения в виде заключения под стражу (ст. 98 УПК РФ).

На взгляд автора, существующая ситуация, при которой возможно избрание в органы государственной власти и органы местного самоуправления лиц, находящихся в федеральном розыске, содержащихся под стражей, привлеченных в качестве обвиняемых по уголовным делам, неоднократно судимых, в том числе по тяжким составам преступлений, недопустима. По странному стечению обстоятельств в российском законодательстве требования к народным представителям - депутатам и выборным должностным лицам всех уровней - существенно мягче, чем, например, требования к судьям, прокурорам, сотрудникам правоохранительных органов и спецслужб.

Согласно пункту 1 статьи 4 Закона Российской Федерации «О статусе судей в Российской Федерации», пункту 2 статьи 40.1 Закона Российской Федерации «О прокуратуре Российской Федерации», пунктам 2 и 3 части 1 статьи 29 Федерального закона «О полиции», подпункту 4 пункта 5 статьи 18 Федерального закона «О государственной охране», пункту «в» части 3 статьи 16 Федерального закона «О федеральной службе безопасности», гражданин, имеющий судимость (в том числе снятую или погашенную), а также в отношении которого уголовное преследование прекращено за истечением срока давности, в связи с примирением сторон, вследствие акта об амнистии или в связи с деятельным раскаянием, никогда не сможет поступить на службу или на работу в органы прокуратуры, полиции, органы государственной охраны, федеральной службы безопасности, не может быть назначен на должность судьи. Однако тот же самый гражданин беспрепятственно изберется в Государственную Думу Федерального Собрания Российской Федерации, законодательный орган государственной власти субъекта Российской Федерации, в представительный орган муниципального образования, на любую выборную должность!

Гражданин, зарегистрировавший за пределами Российской Федерации право собственности на имущество, в соответствии с пунктом «д» части 3 статьи 16 Федерального закона «О федеральной службе безопасности», 
подпунктом 6 пункта 5 статьи 18 Федерального закона «О государственной охране» подлежит увольнению из органов федеральной службы безопасности или органов государственной охраны. Но если этот гражданин избирается или уже избран депутатом Государственной Думы Федерального Собрания Российской Федерации, депутатом законодательного органа субъекта Российской Федерации, депутатом представительного органа муниципального образования, выборным должностным лицом, то никаких проблем для него не возникает!

При этом полномочия депутатов, выборных должностных лиц и характер принимаемых ими политико-правовых решений непосредственно затрагивают права и свободы граждан. Противоправное использование властных полномочий может представлять угрозу единству и территориальной целостности, обороноспособности государства, единству правового и экономического пространства Российской Федерации. Наличие же имущества на праве собственности, вкладов в банках за пределами Российской Федерации, участие в иностранных коммерческих организациях влияет на объективное исполнение должностных обязанностей и депутатских полномочий, способно привести к причинению вреда законным интересам граждан, организаций и государства.

В целях устранения названных «двойных стандартов» часть 1 статьи 4 Ф3 «О статусе члена Совета Федерации и статусе депутата Государственной Думы Федерального Собрания Российской Федерации» предлагается дополнить пунктом «к», в котором в качестве самостоятельного основания досрочного прекращения полномочий члена Совета Федерации, депутата Государственной Думы будет закреплено приобретение зарегистрированного за пределами Российской Федерации права собственности на имущество. Пункт 4 статьи 12 Федерального закона «Об общих принципах организации законодательных (представительных) и исполнительных органов государственной власти субъектов Российской Федерации» необходимо изложить в следующей редакции: «Утрата депутатом гражданства Российской Федерации, приобретение им гражданства иностранного государства либо получение им вида на жительство или иного документа, подтверждающего право на постоянное проживание гражданина Российской Федерации на территории иностранного государства, приобретение зарегистрированного за пределами Российской Федерации права собственности на имущество, является основанием для досрочного прекращения депутатских полномочий».

В Федеральный закон «Об основных гарантиях избирательных прав и права на участие в референдуме граждан Российской Федерации» было бы целесообразно внести следующие изменения. Подпункты «а» и «б» пункта 3.2 статьи 4 комментируемого Федерального закона изложить в редакции: «Не имеют права быть избранными граждане Российской Федерации: а) 
имеющие судимость, в том числе снятую или погашенную ${ }^{1 ;}$ б) в отношении которых уголовное преследование было прекращено за истечением срока давности, в связи с примирением сторон, вследствие акта об амнистии, в связи с деятельным раскаянием».

Если данные предложения о внесении изменений в Федеральный закон «О статусе члена Совета Федерации и статусе депутата Государственной Думы Федерального Собрания Российской Федерации», Федеральный закон «Об общих принципах организации законодательных (представительных) и исполнительных органов государственной власти субъектов Российской Федерации» и Федеральный закон «Об основных гарантиях избирательных прав и права на участие в референдуме граждан Российской Федерации» не получат полноценное развитие в законодательных актах Российской Федерации, то минимально необходимым средством борьбы с криминализацией органов публичной власти представляется сделать хотя бы обязательность указания кандидатами в депутаты и (или) на выборные должности всех имеющихся судимостей (в т.ч. снятых и погашенных).

В рамках дальнейшего противодействия проникновению лиц, причастных к преступной деятельности, в органы государственной власти и органы местного самоуправления в Федеральных законах «Об основных гарантиях избирательных прав и права на участие в референдуме граждан Российской Федерации», «О выборах Президента Российской Федерации», «О выборах депутатов Государственной Думы Федерального Собрания Российской Федерации» предлагается закрепить обязательность указания кандидатами в депутаты и (или) на выборные должности всех имеющихся судимостей (в т.ч. снятых и погашенных). Пункт 58 статьи 2 Федерального закона «Об основных гарантиях избирательных прав и права на участие в референдуме граждан Российской Федерации» предлагается изложить в следующей редакции: «Сведения о судимостях кандидата - сведения о судимостях с указанием номера (номеров) и наименования (наименований) статьи (статей) Уголовного кодекса Российской Федерации, на основании которой (которых) был осужден кандидат, наименования суда, вынесшего приговор, срока и вида наказания, даты освобождения, а также статьи (статей) уголовного кодекса, принятого в соответствии с Основами уголовного законодательства Союза ССР и союзных республик, статьи (статей) закона иностранного государства, если кандидат был осужден в соответствии с указанными законодательными актами за деяния, признаваемые преступлением действующим Уголовным кодексом Российской Федерации».

Эффективность законодательного противодействия криминализации выборных органов власти можно было бы повысить путем дополнения пункта 3.2 статьи 4 Федерального закона «Об основных гарантиях избирательных прав и права на участие в референдуме граждан Российской

1 Лицо должно быть осуждено за деяния, признаваемые преступными действующим Уголовным кодексом Российской Федерации. 
Федерации» подпунктом «д» - «осужденные за совершение преступлений, предусмотренных статьями 141, 141.1, 142, 142.1 Уголовного кодекса Российской Федерации» ${ }^{1}$. Аналогичные правовые положения следует включить в часть 4.2 статьи 5 Федерального закона «О выборах депутатов Государственной Думы Федерального Собрания Российской Федерации» и пункт 5.2 статьи 3 Федерального закона «О выборах Президента Российской Федерации». Таким образом, лица, имеющие судимость по делам, связанным с нарушением законодательства о выборах и референдумах, не смогут избираться в органы государственной власти и органы местного самоуправления.

В практике избирательных комиссий возникают серьезные затруднения с проверкой наличия имущества за пределами территории России, наличия иностранного гражданства либо вида на жительство на территории иностранного государства.

Нормативным правовым актом, регламентирующим предоставление избирательным комиссиям информации о наличии (отсутствии) у граждан Российской Федерации гражданства иностранного государства либо вида на жительство или иного документа, подтверждающего право на постоянное проживание гражданина России на территории иностранного государства, является Постановление Правительства Российской Федерации от 29 июня 2011 г. № 511 «О мерах по оказанию содействия избирательным комиссиям в реализации полномочий при подготовке и проведении выборов депутатов Государственной Думы Федерального Собрания Российской Федерации шестого созыва и выборов Президента Российской Федерации»².

Следует отметить, что подобного рода сведения предоставляются МИД России лишь по запросам Центральной избирательной комиссии Российской Федерации применительно к федеральным избирательным кампаниям ${ }^{3}$.

В период проведения выборов депутатов Государственной Думы Федерального Собрания Российской Федерации пятого созыва по заявлению ЦИК России Верховным Судом Российской Федерации была отменена регистрация ряда кандидатов в депутаты Государственной Думы, включенных в зарегистрированные федеральные списки кандидатов, в связи с отсутствием у них гражданства Российской Федерации либо наличием гражданства иностранного государства ${ }^{4}$.

1 Данное предложение приобретет актуальность, если не будут реализованы сформулированные автором меры по ограничению пассивного избирательного права в связи с наличием судимости, а также прекращением уголовного преследования за истечением срока давности, в связи с примирением сторон, вследствие акта об амнистии, в связи с деятельным раскаянием.

${ }^{2}$ СЗ РФ. 2011. № 28. Ст. 4209.

${ }^{3}$ Порядок, сроки и формы взаимодействия избирательных комиссий других уровней (избирательных комиссий субъектов Российской Федерации, комиссий муниципальных образований, окружных и территориальных комиссий) с МИД России при проведении региональных и муниципальных выборов нормативно не урегулированы.

${ }^{4}$ Решение Верховного Суда Российской Федерации от 9 ноября 2007 года № ГКПИ 07-1426 по заявлению ЦИК России об отмене регистрации кандидата в депутаты 
Представление кандидатами недостоверных сведений о себе может быть вызвано забывчивостью, техническими ошибками и необходимостью сознательного введения организаторов выборов и избирателей в заблуждение. Так, лица, имеющие погашенные судимости, в ряде случаев сознательно искажают свои установочные данные (отчество, дату рождения). Это затрудняет проверки указанных граждан по учетам ФГБУ «ГИАЦ МВД России» и информационных центров территориальных органов МВД России и дает возможность избираться в органы государственной власти ${ }^{1}$.

Отдельные кандидаты сознательно искажают сведения об образовании. В ходе проверок контрольно-ревизионными службами было выявлено несколько таких фактов.

Например, временно не работающие кандидаты политической партии «ПАТРИОТЫ РОССИИ» Нагуманов Сергей Александрович и Горокоев Идрис Султанович, а также кандидат Коммунистической партии Российской Федерации генеральный директор ООО «Электроника-НН» Кузнецов Сергей Юрьевич сообщили недостоверные сведения о своем образовании. Дипломы государственных образовательных учреждений с указанными ими сериями и регистрационными номерами не выдавались и в книге регистрации выданных дипломов не значатся²

Максимальное количество кандидатов, подавших недостоверные сведения о размере и об источниках доходов, было в федеральном списке политической партии СПРАВЕДЛИВАЯ РОССИЯ - 134. 15 кандидатов Справедливой России представили недостоверные сведения о недвижимом имуществе, 2 - о транспортных средствах ${ }^{3}$.

38 кандидатов Либерально-демократической партии России указали недостоверные сведения о доходах, 3 - о недвижимом имуществе, 3 - о транспортных средствах ${ }^{4}$.

Государственной Думы Федерального Собрания Российской Федерации пятого созыва Наджаряна С.Н., включенного в зарегистрированный федеральный список кандидатов, выдвинутый политической партией «Либерально-демократическая партия России»; Решение Верховного Суда Российской Федерации от 24 ноября 2007 года № ГКПИ 071534 по заявлению ЦИК России об отмене регистрации кандидата в депутаты Государственной Думы Федерального Собрания Российской Федерации пятого созыва Нисанова Г.С., включенного в зарегистрированный федеральный список кандидатов, выдвинутый политической партией «Либерально-демократическая партия России».

1 В ряде субъектов Российской Федерации материалы оперативно-справочных учетов информационных центров МВД, ГУВД, УВД субъектов Российской Федерации сознательно искажаются коррумпированными сотрудниками правоохранительных органов.

2 Сведения о выявленных фактах недостоверности сведений, представленных кандидатами о себе. Специальный информационный выпуск ЦИК России // Рос. газ. 2011. 4 декабря. С. 192, 196.

\footnotetext{
${ }^{3}$ Там же. С. $187-190$.

${ }^{4}$ Там же. С. С. 190.
} 
57 кандидатов политической партии «ПАТРИОТЫ РОССИИ» предоставили недостоверные сведения о доходах, 20 - о недвижимом имуществе, 10 - о транспортных средствах ${ }^{1}$.

94 кандидата политической партии «Коммунистическая партия Российской Федерации» указали недостоверные сведения о доходах, 22 - о недвижимом имуществе, 13 - о транспортных средствах ${ }^{2}$.

Недостоверные сведения о доходах предоставили 74 кандидата Российской Объединенной демократической партии «ЯБЛОКО», 18 кандидатов указали неверные сведения о недвижимом имуществе, 6 - о транспортных средствах ${ }^{3}$.

52 кандидата Всероссийской политической партии «ПРАВОЕ ДЕЛО» указали недостоверные сведения о доходах, 27 - о недвижимом имуществе, 1 - о транспортных средствах ${ }^{4}$.

Минимальное количество кандидатов, указавших недостоверные сведения о своих доходах и недвижимом имуществе, было в федеральном списке Всероссийской политической партии «ЕДИНАЯ РОССИЯ» (3 и 6 соответственно). Недостоверных сведений о транспортных средствах кандидатами Единой России представлено не было 5 .

Повысить ответственность политических партий, кандидатов в депутаты и улучшить качество народного представительства можно было, вернувшись к практике исключения кандидатов из партийных списков за предоставление ими недостоверных сведений и подложных документов.

Часть 4 статьи 44 Федерального закона «О выборах депутатов Государственной Думы Федерального Собрания Российской Федерации» следовало бы дополнить пунктом 10 следующего содержания: «Центральная избирательная комиссия Российской Федерации исключает кандидата из федерального списка кандидатов в случае представления кандидатом подложных документов или заведомо ложных сведений при его включении в состав федерального списка кандидатов». Часть 9 статьи 91 данного Федерального закона нуждается в дополнении пунктом 6: «Регистрация кандидата, включенного в зарегистрированный федеральный список кандидатов, выдвинутый политической партией, может быть отменена Верховным Судом Российской Федерации по заявлению Центральной избирательной комиссии Российской Федерации, иной политической партии, федеральный список кандидатов которой зарегистрирован, в случаях: ... установления факта представления кандидатом подложных документов или заведомо ложных сведений».

В пункт 24 статьи 38 Федерального закона «Об основных гарантиях избирательных прав и права на участие в референдуме граждан Российской Федерации» представляется целесообразным включить подпункт «п», в

\footnotetext{
${ }^{1}$ Там же. С. 191-192.

2 Там же. С. 193-196.

${ }^{3}$ Там же. С. 196-198.

${ }^{4}$ Там же. С. 199-200.

${ }^{5}$ Там же. С. 198.
} 
котором в качестве основания отказа в регистрации кандидата предусмотреть представление кандидатом подложных документов или заведомо ложных сведений.

Аналогичное основание для исключения кандидата из заверенного списка кандидатов, а также для отмены регистрации кандидата судом по заявлению зарегистрировавшей кандидата избирательной комиссии, кандидата, зарегистрированного по тому же избирательному округу, можно было бы закрепить в подпункте «к» пункта 26 статьи 38 и подпункте «и» пункта 7 статьи 76 комментируемого Федерального закона.

Было бы логично исключить пункт 4 статьи 33 Федерального закона «Об основных гарантиях избирательных прав и права на участие в референдуме граждан Российской Федерации», который предусматривает возможность не представления кандидатами в депутаты представительных органов муниципальных образований в избирательные комиссии сведений о размере и об источниках доходов, а также об имуществе, принадлежащем кандидату на праве собственности, о вкладах в банках и ценных бумагах.

В заключение необходимо упомянуть практику выдвижения отдельными парламентскими партиями популярных государственных и общественных деятелей в общефедеральной части партийных списков и во главе региональных групп кандидатов. Эти лидеры «продвигают» в федеральный и региональные законодательные органы власти основное количество кандидатов, включенных в списки, а затем без каких-либо юридических последствий отказываются от полученных мандатов.

В целях ограничения практики отказа лидеров партийных списков от получения депутатских мандатов пункт 6 статьи 70 Федерального закона «Об основных гарантиях избирательных прав и права на участие в референдуме граждан Российской Федерации» предлагается изложить в следующей редакции: «Соответствующая избирательная комиссия после определения результатов выборов извещает об этом зарегистрированного кандидата, избранного депутатом, выборным должностным лицом, после чего он обязан в пятидневный срок представить в соответствующую избирательную комиссию копию приказа (иного документа) об освобождении его от обязанностей, несовместимых со статусом депутата, выборного должностного лица, либо копии документов, удостоверяющих подачу в установленный срок заявления об освобождении от указанных обязанностей. Если зарегистрированный кандидат, признанный избранным по результатам голосования за список кандидатов, не выполнит указанное требование или откажется от мандата, он исключается из списка кандидатов, а его депутатский мандат считается вакантным. При этом такой мандат не может быть передан другому зарегистрированному кандидату из того же списка кандидатов, в составе которого был избран депутат, который не выполнил требования об освобождении его от обязанностей, несовместимых со статусом депутата, либо отказался от мандата. Вакантный мандат передается следующему в порядке убывания числа поданных голосов избирателей списку кандидатов. Если зарегистрированный кандидат, избранный 
депутатом по одномандатному (многомандатному) избирательному округу либо избранный выборным должностным лицом, не выполнит указанное требование, соответствующая избирательная комиссия отменяет свое решение о признании кандидата избранным».

Данное изменение закона позволит прекратить практику введения избирателей в заблуждение и защитит их конституционные права. 